Miłosz GAC

WSB University, Faculty of Finance and Management, Gdańsk, Poland

\title{
Maritime Safety of NATO Borders in the Baltic Sea Region
}

\author{
Bezpieczeństwo morskich granic NATO \\ w regionie Morza Bałtyckiego
}

\section{- Abstrakt •}

Region Morza Bałtyckiego jest specyficznym obszarem leżącym na styku sprzecznych interesów politycznych Wschodu i Zachodu, co sprawia, że jest obiektem szczególnego zainteresowania tak Sojuszu Północnoatlantyckiego, jak i Federacji Rosyjskiej. Obecną sytuację charakteryzuje wysoka militaryzacja tego rejonu, związana przede wszystkim z wykorzystaniem rosyjskiego sektora siłowego, a szczególnie zdolności przeciwdostępowych w Obwodzie Kaliningradzkim. Zmiany w środowisku bezpieczeństwa na tym obszarze spowodowały zwiększenie zdolności do odstraszania i zbiorowej obrony wszystkich członków NATO w ramach wzmacniania wschodniej flanki Sojuszu.

Słowa kluczowe: Rosja; NATO; region Morza Bałtyckiego; Baltops

\section{- Abstract •}

The Baltic Sea Region (BSR) is a specific area lying between the areas of conflicting political interests of the East and West, making it an object of particular interest of the North Atlantic Treaty Organisation and the Russian Federation. The current situation is characterized by the high militarization of the region, mainly related to the use of the Russian power sector, with the anti-access capabilities in the Kaliningrad District in particular. Changes in the security environment in this area have resulted in the increased capabilities to deter and the collective defence capabilities of all NATO members, as part of strengthening the Alliance's eastern flank.

Keywords: Russian Federation; NATO; Baltic Sea Region; Baltops

\section{Introduction}

The Baltic Sea Region has a special role in the maritime safety strategy of the Baltic Sea members of the North Atlantic Alliance. This region is an important 
area of sea transport, trade exchange and collection of living and non-living resources. In addition, its strategic importance is strengthened by the presence of the longest sea gas pipeline in the world - the Nord Stream. Direct access to the Baltic Sea is not only a space for economic activity but above all an opportunity to shape the regional political situation, thus affecting the adjacent countries. In recent years, the military factor has become the basic tool for achieving political goals in the Baltic region. The Russian Federation has become an example for the practical use of the military, which again began to manifest geopolitical ambitions aimed at gaining a dominant role in the post-Soviet areas. Russia's demonstration of strength primarily takes the form of large-scale military manoeuvres aimed at changing the security architecture in the Baltic Sea Region. The increased scope and frequency of the manoeuvres go hand in hand with the notoriety in violation of the airspace and the territorial waters of the Baltic states. Such activities pose a particular threat to the critical maritime infrastructure of NATO countries, in particular for ports and the homing places. Russia's aggressive attitude resulted in the representatives of the NATO Member States deciding to strengthen the eastern treaty area. The most important decisions in this matter were made at the NATO summit in Warsaw, where a coherent position against Russia's aggressive and assertive behaviour was presented. The key assumption adopted thereon was the introduction of a military factor in the form of NATO forces permanently regrouping to the countries of Eastern Europe. Changes in the strategic concept of the NATO Alliance, aimed at increasing the presence of the United States in the Baltic region, have been confirmed by the next summits held in Brussels. The adoption of integrated defence strategy meant there was a need to adapt military structures to new challenges, in the maritime domain in particular. The most important initiative of the North Atlantic Alliance in this regard was to strengthen the speed and the ability to respond. The BALTOPS military manoeuvres, which put a special emphasis on the rapid strengthening of allies from both water and air, are suitable for the implementation of these tasks.

The aforementioned introduction to the topic resulted in the formulation of the main research problem expressed by the query: What actions does NATO take to ensure the safety of maritime borders in the Baltic Sea Region? In order to solve the main research problem, the following specific problems were added:

1) Is the maritime strategy of the Russian Federation in the Baltic Sea Region threatening the security of NATO Member States?

2) What strategy has NATO adopted against Russia in the Baltic region? 


\section{Maritime Strategy of the Russian Federation in the Baltic Sea Region}

The Baltic Sea Region in Russian security policy is a classic maritime, political and strategic area. This is due to its location as a region that allows to create the European policy by influencing neighbouring countries, in particular the Baltic states. Such determination of the importance of the Baltic Sea in the Russian security policy can be described as weakening the influence of the United States in the region and disintegrating the European Union. Strong influence on neighbouring countries has the strategic aim of leading to the restoration of the influence zone from the times of the Soviet Union (Gac, 2018, p. 14). This purpose is executed by a high degree of militarization in the region, broadly understood as military presence, allowing the force projection against NATO.

Russian military and maritime activities in the Baltic region can be summarised by two scenarios. The first focuses on the expansion of combat capabilities in the Kaliningrad region, which would allow to increase the impact capabilities and to create a so-called Anti-Access Zone (A2/AD; Eberhardt \& Menkiszak, 2016, p. 18). Such strategy is associated with the development of maritime potential, the main element of it being the military fleet and demonstrating its military strength. In the Baltic Sea Region, this task is carried out by the Baltic Fleet, part of the Western Military District. Its structure consists of 67 battleships, 240 different sizes of auxiliary vessels, about 50 aircraft and helicopters, as well as a land component (Chała, 2017, p. 11). This potential was divided into two groups - North and South. The forces assigned to the first one are stationed in the Leningrad oblast in Kronstadt harbour on the Gulf of Finland. The most important of them are the school ships of the 887 project "Smolnyj", cutters of the UK-3 project and two conventional submarines - the B-227 "Vyborg" and the B-806 "Dimitrov". In the near future, the "Vyborg" unit is planned to be withdrawn from the service and transferred to a branch of the military-patriotic recreation park of the Armed Forces of the Russian Federation "Patriot" in Kronstadt (Minak, 2018). Its place in the ranks of the Baltic Fleet will be taken by the "Alrosa" submarine, equipped with a water-thrust propeller. Thus, it will be the quietest unit among Russian "Warszawianka" type submarines (Minak, 2018).

Southern grouping placement takes part in the Baltic Sea Base in Baltiysk in the Kaliningrad oblast. Most ships with offensive potential are stationed here, such as the destroyer "Nastojczivyj", 2 project 11540 frigates "Jastreb", "Nieustraszimyj" and "Jaroslaw Mudryj", as well as four corvettes of the 20380 project - "Stiereguszczyj", "Sobrazitielnyj", and "Boykiy". It is worth noting that the 36 Brigade of Missile Ship operates within the Southern Group, with four 
rocket launcher cutters from project 1411T "Molnija" and two 12441T projects "Kuznieck" (Chała, 2017, p. 13). In addition to numerous combat ships and cutters in the ranks of the Baltic Fleet, there are also four radio-electronic reconnaissance ships. Their main tasks include capturing the opponent's communications and any other signals emitted by their military devices. These units specialize in tracking the operation of anti-missile systems, mainly those belonging to NATO. Such vessels include the rebuilt 503R fishing trawlers and two large, built from scratch, 864 unit "Miedidian" (Chała, 2017, p. 13).

Apart from vessels, the Baltic Fleet also includes land units and air forces. The land impact potential consists of about 40 T-72B tanks, 159 MT-LB amphibious transporters, 85 BMP-2 infantry fighting vehicles, 54 Akataja 2S3 self-propelled guns, 15 sets of 2S6M "Tunguska" and 12 self-propelled 9K79-1 missile launchers "Toczka-U" (Chała, 2017, p. 13). The aviation component is represented by five squadrons subordinate to the $72^{\text {th }}$ Guardian Air Force Base in Czkałowsko, which have a large number of aircraft and helicopters, such as: $\mathrm{Su}-24, \mathrm{Su}-27, \mathrm{An}-26, \mathrm{Mi}-$ 24, Mi-8, and Ka-27.

The present strength of the Baltic Fleet was a result of the organizational changes from 2016. They resulted from the provisions of the Maritime Doctrine of the Russian Federation dated 26 July 2015, being in fact a military response to NATO moving closer towards the Russian borders (Symonides, 2016, p. 11).

Equipping with the S-400 air defence system, rocket-artillery anti-aircraft missile shield Pancyr-S1 were the key element of the Baltic Fleet combat capabilities increase (Dura, 2017). This system is designed to target and then direct the missiles to the enemy planes and manoeuver missiles at a distance of 400 kilometres. The $25^{\text {th }}$ Air Defence Missile Regiment was also included in the implementation of the Baltic Fleet modernisation program, and was rearmed with the new missile system "Bastion", which purpose is to destroy large ship groupings, including aircraft carrier teams (Wilk, 2016). The "Bastion" systems consist primarily of "Onyx" rockets, moving at a speed of 2.5 thousand $\mathrm{km} / \mathrm{h}$ and able to prevent the NATO ships from exiting the Baltic Sea in the Danish straits area. It is worth noting that the "Bastion" systems have the ability to launch "Kalibr" manoeuvring missiles, the strength of which was manifested in the attack performed by the "Rostov-on-Don" submarine on the "capital" of the Islamic State in Syria (Symonides, 2016, p. 24). In addition, "Kalibr" rockets are the equipment of small type "Bujan-M" rocket ships (project 21631), which serve in the Baltic Sea area since 2016. Interestingly, these ships, with an expanded operation area, are difficult to detect, and are therefore considered to be some of the quietest ones, often colloquially called "the black holes" (Symonides, 2016, p. 24). This strengthening 
of the Baltic Fleet considerably extends its tactical activities, giving the possibilities that no other state in the Baltic Sea has.

The range of the Baltic Fleet's attack capabilities is extended by missile units equipped with "Iskander" ballistic systems. These missiles can damage targets within $500 \mathrm{~km}$ distance, thus posing a threat to the critical infrastructure of the entire Baltic Sea Region, in particular to all NATO forces deployed in Central-Eastern Europe. It should be noted that Iskanders can carry nuclear cargo with a weight of $480 \mathrm{~kg}$ to $720 \mathrm{~kg}$, which is an effective element of propaganda and psychological warfare, remaining in line with the deterring of the North Atlantic Alliance policy (Eberhardt \& Menkiszak, 2016, p. 18).

The second scenario of Russia's military activity also makes use of the expansion of the Baltic Fleet and concentrates on military provocations. The increased activity of the Russian armed forces is visible by numerous sea manoeuvres in the Baltic Sea. The choice of the place for the exercises is not accidental, though usually they take place close to the borders between the states of the North Atlantic Alliance (Ścibiorek, 2017, p. 30). Russian-Belarusian manoeuvres Zapad 2017 were an example of such operational and strategic exercises in the Baltic region. In addition to the land and air components, the Baltic Fleet took part in them, which according to the official communication, improved tasks in the field of anti-submarine, anti-aircraft defence and anti-mine tasks. In fact, the A2/AD (Anti-Access/Area Denial) methods were trained, where the marine component of the Baltic Fleet, strengthened by the "Bastion" shore rocket complexes and "Iskander" ballistic missiles, practiced offensive actions. The corvettes "Soobrazitielnyj", "Boykai", "Stojkij", and "Stierieguszczij", were among the units participating in the manoeuvres, faking the attack against enemy units and activating artillery fire of air targets imitating the means of air attack (Wróbel, 2017).

The manoeuvres of the Baltic Fleet during Zapad 2017 are part of the current maritime strategy of the Russian Federation, which aim is to undermine stability and peace in the Baltic region. The information is confirmed by the Stockholm daily Svenska Dagbladet, writing that under disguise of defensive manoeuvres, the Russian armed forces in fact practiced invasion of Poland and the Baltic states (Ryska övningen större än..., 2017).

In Russia's attempt to control the post-Soviet area and block all NATO initiatives of getting close to its borders, military cooperation with China is included. An example of this can be the Russian-Chinese sea exercise under the code name "Sea Cooperation 2017". One of the most modern ships of the Chinese navy, the destroyer "Hefei", took part in the manoeuvres, supported by the Russian corvette of the new generation "Stierieguszczij" and "Boykai" (Radziwinowicz, 2017). 
In the official communication, the main objective of the exercises was for the Russian and Chinese navies to cooperate in counteracting threats to maritime safety, including organizing anti-aircraft defences and fighting submarines and surface ships (Radziwinowicz, 2017). Despite the small scale of the manoeuvres, they were evidently an element of the political game, which constituted a clear military signal towards the North Atlantic Alliance.

The meaningful actions of the Russian Navy serve to strengthen the Baltic Fleet management system and reconstruct the strategic positions in the Baltic Sea Region. Thus, it should be emphasized that the rapid militarization process in the Baltic area is the greatest threat to NATO countries.

\section{NATO Strategy in the Baltic Sea Region}

The strategic ambitions of the Russian Federation aimed at isolating the battlefield and establishing the Anti-Access/Area Denial in the Baltic Sea Region forced the launch of decision-making processes in the North Atlantic Alliance. The first step to ensure capabilities that would meet the new challenges and threats was the North Atlantic Council meeting at the Heads of Member States level at the Newport Summit on 4-5 September 2014. The key decisions of the Welsh summit included the approval of the Readiness Action Plan (RAP) aiming at strengthening the capacity in the area of crisis management (Banasik, 2015, p. 59). The plan included the adaptation of measures necessary to ensure full safety capability, resulting in the maintenance of a continuous and rotational presence of troops on land, sea and air in the countries of the eastern flank and in the Baltic Sea area (Banasik, 2015, p. 59).

The essence of the actions taken was the reform of the NATO Response Force (NRF). The NRF, in accordance with the guidelines of the Military Committee for the NATO Response Force, is a multinational, highly mobile, interoperable module, capable of immediate transfer into a region of crisis. They consist of land, air and sea component, and thus have the capacity to perform the full range of NATO missions. The Land Component Headquarters (LCHQ) operates on the basis of one of the seven land commands of the High-Force Corps (ARRC, Eurocorps), along with Italian, Turkish, Spanish, German-Dutch and French corps. Air Component Headquarter (ACHQ) is formed on the basis of one of the NATO Air Force Commanders and the National Air Force Command declared by the Member States. The Maritime Component Headquarter (MCHQ), in turn, operates on the basis of one of the naval commands of NATO's High Readiness 
Forces, having under itself naval forces composed of landing forces, minesweepers and auxiliary vessels, as well as air patrol teams supported by an aircraft carrier combat group (Ligęza, 2013, p. 154).

As part of the NATO Response Force reform, it was established to create forces with very high readiness to take action, the so-called "Very High Readiness Joint Task Force (VJTF)" (Lorenz, 2015, p. 1). This formula assumed the formation of a unit of the size of a land forces brigade, about 5,000 soldiers, which would be supported by other types of armed forces (Banasik, 2015, p. 59). In addition, the assumption was made that the deployment of the VJTF in the area of the crisis would take place within 2-5 days after the decision was made. In order to ensure VJTF adaptability, it was agreed that specific allied procedures should be implement during the exercise. The first manoeuvres putting NATO's "spear" to test were the Noble Jump exercises, which took place in June 2015 in Poland. The main objective of the exercises was to increase the interoperability and readiness of NATO states to jointly engage in collective defence. It should be emphasized that during these manoeuvres, there were also sea exercises focusing on sea landing training. The series of exercises conducted in the Baltic Sea Region were a demonstration of collective defence of NATO and, at the same time, a tangible result of implementing the Newport provisions. Thus, the Welsh summit gave a new impulse in the process of strategic adaptation of NATO to the changing security conditions in the Baltic region.

The changes in NATO's strategic concept were sealed during the summit in Warsaw on 8-9 July 2016. Its most important resolutions included the deployment of four multinational battalion battle groups in Poland and the Baltic States. During the summit, it was agreed that allied combat groups would include about 1,000 soldiers. The largest contribution would be provided by the framework nations as follows: the United States in Poland (about 1000 soldiers), Germany in Lithuania (about 600 soldiers), Canada in Latvia (about 450 soldiers), and Great Britain in Estonia (about 500 soldiers; Kacprzyk, 2016). In addition to deploying of NATO operations battalions, it was decided to strengthen bilateral cooperation between the United States and the countries of the region. The consequence of this decision was the deployment of the heavy armoured brigade by U.S. Army in Poland.

The last key decision of the Warsaw summit was to approve the construction of the missile shield in Redzikowo near Słupsk. The shield, being part of the NATO anti-missile system, would be equipped with a SM-3 missile battery, able to capture ballistic missiles flying from the East.

Thanks to the summit in Warsaw, the Alliance took into account the Russian strategy in the field of $\mathrm{A} 2 / \mathrm{AD}$ and was ready to introduce changes to the strategic 
concept accordingly. These assumptions were confirmed in subsequent meetings of NATO countries in Brussels in May 2017 and July 2018. The key decisions that took place in the capital of Belgium included the adoption of the $4 \times 30$ initiative, under which the allies undertook to issue 30 mechanized battalions, 30 air squadrons and 30 warships in less than 30 days (Gotkowska, 2018). The above forces would, in the event of a conflict, strengthen the NATO Response Force, which includes the "spearhead" along with air, naval and special forces components, of 40,000 soldiers in total.

To make its response more dynamic, the North Atlantic Alliance increased the frequency of operations of the naval forces in the Baltic Sea Region, designating warships for cooperation within the so-called NATO Permanent Teams. The Team is divided into two types: Permanent NATO Mine Countermeasure Group (SNMCMG 1 and SNMCMG 2) and NATO's Permanent Maritime Groups (SNMG 1 and SNMG 2; Ligęza, 2013, p. 154). The aforementioned teams of ships, while using maritime persuasion in order to confirm the presence of NATO naval forces in the Baltic, perform tasks related to immediate response to threats. The main goal of the international teams' activities is the mutual and internal integration of NATO maritime forces through the operation of individuals from many countries within a single Team (Ligęza, 2013, p. 154). An example of such an action is the increase of exercises and operations at sea. The biggest manoeuvres in the Baltic Sea Region include the Baltic Operations (BALTOPS). These exercises have been taking place for 46 years but their training objectives have changed accordingly, depending on the situation in the region. In the years 1974-1989 they focused primarily on the preparation of American, British, Dutch and Norwegian ships for special navigational and hydrographic present in the Baltic Sea. During this period, the defence system of combat ships groups (CSG) at the sea crossing was improved, with particular focus on the defence against submarines, surface ships and anti-aircraft defences. The key element of the BALTOPS exercise in 1974-1989 was the passage of ships along the coasts of Poland, the GDR and the USSR, where considerable importance was attributed to the Baltic Straits, in the area of significant forces of the Warsaw Pact.

In the 1990s, BALTOPS ceased to be internal manoeuvres of the North Atlantic Alliance, and opened up for the new states of the former Eastern Bloc. The Russian Federation was also invited to the exercises, which proved that the Baltic Sea Region was transformed into a zone of political and military stabilization. The situation changed as a result of Russia's return to the path of authoritarianism, the aftermath of which were the 2015 BALTOPS manoeuvres without the participation of Russian forces. The changing security environment in the Baltic 
Sea Region resulted in the last editions of BALTOPS exercises focusing on air defence, training with live ammunition, fighting submarines and surface vessels, sea observation and counteracting waterborne operations (Lipiecki \& Błaszczak, 2018, p. 52).

In June 2018, its largest edition in history took place, and the BALTOPS were attended by 4,700 soldiers and over 50 ships from 20 countries of the NATO Alliance. The manoeuvres were organised by the NATO Strike Force and Support Command - STRIKFORNATO (SFN), which goal is to command the operations of the highest readiness forces. The main mission of SFN is to perform a full spectrum of naval operations, including deterrence and collective defence under Article 5 of the Washington Treaty, as well as emergency response and peace support operations. In BALTOPS 2018 manoeuvres, Blue Ridge "USS Mount Whitney" LCC-20 took the place of the flagship and served as the commander to the striking ships. The far guard for the allied landing forces was performed by rocket frigates included in NATO's permanent response force team: the Norwegian F312 "HNoMS Otto Sverdrup" and the Spanish SPS F101 "Alvaro de Bazan" (Lipiecki \& Błaszczak, 2018, p. 49). The other impact forces participating in the exercises include the American missile destroyer USS DDG-96 "Bainbridge" and the British frigate missile HMS F235 "Monmouth", which are equipped with an integrated detection, guidance and fire control system - AEGIS (Aegis Combat System). BALTOPS battleships were traditionally supported by anti-mine units. In the 2018 edition, the minesweepers were focusing on so-called fleetex rigs so that the missile ships could perform their key tasks.

The units mentioned above focused primarily on threats and reactions to the hybrid war, including propaganda actions in social media, as well as on scenarios to stop rebels operating for another country. It should be emphasized that the above measures are difficult to counteract with the use of larger vessels, therefore for this purpose the fast Royal Navy boats are used, focusing on coastal activities.

It should be emphasized that BALTOPS exercises are one of the main mechanisms for strengthening cooperation between NATO and its members in the Baltic region. The co-operation of the countries in the region is particularly important, due to the need to show the capability of Alliance ships to counteract threats and response quick to crises in the Baltic Sea.

To sum up, the projection of the Russian Federation's strength in the Baltic Sea Region caused a reaction from the North Atlantic Alliance, which began to rebuild its collective defence capability. The actions initially focused on fulfilling allied commitments, and after the summit in Warsaw, also on measures to deter Russia. NATO's extended presence in the Baltic region is aimed primarily at a more 
complete monitoring of the situation in this area, as exemplified by the increased frequency of naval forces operations.

\section{Conclusion}

In conclusion, due to the geopolitical manifestations of the Russian Federation, the Baltic Sea Region once again became an area of great strategic importance. The military and maritime activity of Russia focuses primarily on creating favourable conditions for the implementation of its key security priorities. This is to be served by the maritime doctrine, the aims of which are to regain geopolitical control over the Baltic countries and to move military infrastructures towards the borders of NATO. Strengthening the military potential of Russia in the Baltic region is confirmed by numerous military manoeuvres that indicate the possibility of establishing an Anti-Access/Area Denial area in the Baltic. Offensive and defensive A2/AD systems undoubtedly constitute a challenge for NATO units limiting their shifting and freedom of manoeuvre.

The increasing level of readiness of the Russian fleet forced the Alliance to adjust the structures of NATO to new maritime challenges. The change in approach to the execution of new tasks arising for the Alliance was evident during NATO summits in Newport and Warsaw. Decisions taken by the leaders of the Member States have resulted in actions to strengthen their own armed forces in the Baltic Sea Region. The number of NATO Response Forces was increased, including the frequency of operations by naval forces within the units of the NATO Standing Naval Forces and Standing NATO Mine Countermeasures Group One. Despite the clear positive symptoms, no maritime doctrine was created that would aim at strengthening the position of the region's states in the group of strong sea states. The main reason is the lack of granting the Baltic region a priority region status by NATO structures. As a consequence, there is a need to create a separate strategy for this area, taking into account the regional naval command, responsible for allied support, improving coordination and shortening the time of decision making, which on the whole will make it impossible for Russia to gain advantage in the region. 


\section{References:}

Banasik, M. (2015). NATO w świetle postanowień szczytu w Newport. Bellona, 3(682), 56-68.

Chała, M. (2017). Flota Bałtycka Federacji Rosyjskiej. Morze, 4, 11-18.

Dura, M. (2017). S-400 ćwicza w Obwodzie Kaliningradzkim. Retrieved from: https:// www.defence24.pl/s-400-cwicza-w-obwodzie-kaliningradzkim.

Eberhardt, A., \& Menkiszak, M. (2016). (eds.). Obwód Kaliningradzki 2016: społeczeństwo, gospodarka, armia. Warszawa: Ośrodek Studiów Wschodnich im. Marka Karpia.

Gac, M. (2018). Polska polityka bezpieczeństwa w basenie Morza Battyckiego w okresie Związku Battyckiego oraz w latach 90 XX wieku: próba porównania. Katowice: Wydawnictwo Naukowe SOPHIA.

Gotkowska, J. (2018). Brukselski szczyt NATO: wschodnia flanka między USA a Europa. Retrieved from: https://www.osw.waw.pl/pl/publikacje/analizy/2018-07-09/brukselski-szczyt-nato-wschodnia-flanka-miedzy-usa-a-europa.

Kacprzyk, A. (2016). PISM: NATO musi uwiarygodnić odstraszanie Rosji. Retrieved from: http://biznesalert.pl/pism-nato-musi-uwiarygodnic-odstraszanie-rosji/.

Ligęza, K. (2013). Siły morskie w operacjach reagowania kryzysowego. Gdynia: Akademia Marynarki Wojennej.

Lipiecki, J.S., \& Błaszczak, Ł. (2018). BALTOPS 2018. Morze, Statki i Okręty, 7-8(187), $48-52$.

Lorenz, W. (2015). Szpica NATO potrzebuje tarczy na wschodniej flance. Biuletyn PISM, 15(1252), 1-2.

Minak, K. (2018). The Still Pool. Silent Submarine "Alrosa" Will Strengthen the Baltic Fleet. Retrieved from: https://360tv.ru/news/tekst/tihij-omut/.

Radziwinowicz, W. (2017). Okręty Chin i Rosji ćwiczą na Bałtyku. Moskwa cementuje morskie braterstwo broni z Pekinem. Retrieved from: http://wyborcza.pl/7,75399,22147028,okrety-chin-i-rosji-cwicza-na-baltyku-moskwa-cementuje-morskie.html.

Ryska övningen större än vad som aviserats (2017). Retrieved from: https:/www.svd.se/ ryska-ovningen-storre-an-vad-som-aviserats.

Symonides, J. (2016). Nowa doktryna morska Federacji Rosyjskiej. Bellona, 1(684), 11-28.

Ścibiorek, Z. (2017). Militarne znaki zapytania na Wschodzie. Bellona, 1(688), 20-33.

Wilk, A. (2016). Systemy rakietowe „Bastion” w obwodzie kaliningradzkim - zmiana sytuacji militarnej w Europie Środkowej. Retrieved from: https://www.osw.waw.pl/pl/publikacje/analizy/2016-11-22/systemy-rakietowe-bastion-w-obwodzie-kaliningradzkimzmiana-sytuacji.

Wróbel, A. (2017). Na manewrach Zapad-2017 Flota Battycka ćwiczyła strzelanie artyleryjskie. Retrieved from: http://www.gospodarkamorska.pl/MW,Sluzby-Morskie/na-manewrach-zapad-2017-flota-baltycka-cwiczyla-strzelanie-artyleryjskie.html. 